\title{
PROBLEMS OF RURAL DEVELOPMENT IN VICINITY OF URBAN AGGLOMERATION
}

\author{
Marek Zagroba \\ University of Warmia and Mazury in Olsztyn, Poland \\ mazag@uwm.edu.pl
}

\begin{abstract}
Contemporary rural complexes situated in the vicinity of urban agglomerations are areas extremely vulnerable to influences produced by the nearby living and growing towns. The architecture in these areas is highly diverse and often evokes spatial chaos. The purpose of this paper has been to discuss the issues of shaping the building structure of villages located near an urban agglomeration as affected by the impact of the city's spatial structure. Another aim is to prove the hypothesis that the quality, needs and standards of living of people in a large town have a bearing on the contemporary architecture in the countryside. Olsztyn, a town lying in the Province of Warmia and Mazury (województwo Warmińsko-Mazurskie) in Northeastern Poland, can serve as an example. The structure and territorial development of Olsztyn have a strong influence on the shape of rural architecture in neighbouring villages, for example, in the commune of Dywity, where villages are composed of rural settings that have existed for hundreds of years. The rural areas located within the impact generated by an urban agglomeration are attracting much interest among young people as a potential place to settle down and live. The process of growth in such areas, due to the increased migration of urban population, is frequently a cause of the uncontrolled expansion of new building developments, which leads to distortions in the spatial order. Increasingly often, the traditional architecture of the Polish countryside in the region of Warmia and Mazury, shaped over the past centuries, undergoes degradation because of the new architecture, which has no connection with the region's history. The post-war period, even when contrasted with the losses suffered during the Second World War, has caused immense transformations in the spatial structure of the countryside, resulting from the exchange of the pre- and post-war populations and the construction of brick buildings, replacing traditional timber cottages or farm buildings, thereby introducing a new quality to the cultural landscape of the region.
\end{abstract}

Keywords: architecture of the countryside, ruralistics, suburban development, revitalization.

\section{Introduction}

Rural complexes situated in the vicinity of urban agglomerations are perceived as very attractive locations for building developments. The trend arises from the specific character of lifestyle in contemporary cities, coupled with the needs and aspirations of urban dwellers. In Poland, there is a growing migration of urban populations to the countryside, in search of peace and quiet as well as a close contact with nature. Modern cities and towns do not offer such values and, owing to motor transport, the distance to a town centre and the services it offers is no longer a barrier. The phenomenon called "urban sprawl" may threaten the shape of rural architecture and undermine efforts to maintain spatial order and preserve the identity of rural settlements, many of which have a tradition several centuries long. Urban sprawl often causes uncontrolled development of residential housing, thus reducing villages to "bedrooms" for residents of cities. The traditional countryside buildings and historically shaped spatial layouts of villages in Warmia and Mazury, a region in northeastern Poland, reveal a highly diverse state of preservation [1]. Villages located in the commune Dywity, bordering with Olsztyn, the largest town in this part of Poland, can serve as an example. At present, the commune Dywity consists of 19 villages with an area of $160.68 \mathrm{~km}^{2}$. The population is 10656 people (Table 1).

Table 1

\section{Population of the commune Dywity}

\begin{tabular}{|c|c|c|}
\hline $\begin{array}{c}\text { Population } \\
\text { (people) }\end{array}$ & $\begin{array}{c}\text { Number } \\
\text { of villages }\end{array}$ & Village \\
\hline $0-300$ & 7 & $\begin{array}{c}\text { Barkweda (198), Dąbrówka Wielka (257), Gradki (195), } \\
\text { Myki (142), Nowe Włóki (238), Rozgity (96), Zalbki (129) }\end{array}$ \\
\hline $301-500$ & 6 & $\begin{array}{c}\text { Brąswałd (377), Bukwałd (326), Frączki (303), Gady (353), } \\
\text { Sętal (353), Wadąg (339) }\end{array}$ \\
\hline $501-1400$ & 6 & $\begin{array}{c}\text { Kiézliny (1303), Eugwałd (527), Różnowo (1210), } \\
\text { Słupy (719), Spręcowo (534), Tuławki (526) }\end{array}$ \\
\hline
\end{tabular}


The post-war period, even when contrasted with the huge loss and damage caused by the World War Two, led to larger transformations in the cultural landscape of the region. The causes should be seen in the establishment of the State Agricultural Farms, which in the second half of the 20th century led to the development of housing and farm buildings representing "flat-roof" architecture and being in its form, building materials and scale - completely disconnected from the traditional countryside architecture. The State Farms collapsed, leaving behind the unsightly buildings and the high unemployment due to their liquidation. These factors had an additional negative impact on the quality of rural space. Since then, some villages near Olsztyn have been filled with random housing developments, including large residential properties, to which the town's inhabitants have moved. The above transformations necessitate an appropriate local-scale spatial policy in the space management. Legal documents prepared on locally, such as a commune's local spatial management plans and studies of the conditions and directions of spatial management, play an important role in this context. Their preparation involves many professionals - architects, urban studies specialists, economists, demographic specialists, sociologists, lawyers, historic environment conservators, etc.

The objective of this article is to present the problem of shaping the rural building developments in the commune Dywity, lying within the impact zone of Olszyn, the capital city of the region of Warmia and Mazury, in northeastern Poland. The research method consists of an analysis of the state and form of buildings in the rural surroundings of the commune. The research results justify the conclusion that the contemporary shape of rural buildings and their complexes is affected by a variety of factors (Fig. 1;2).

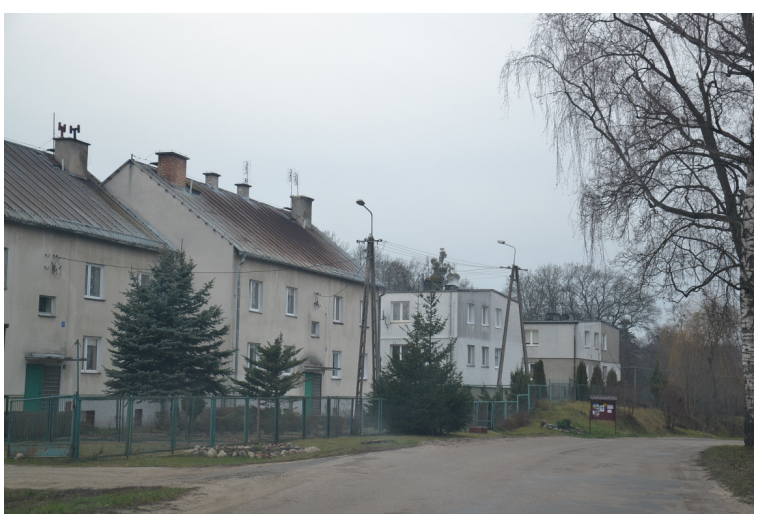

Fig. 1. Barkweda - buildings of a former State Farm in the village

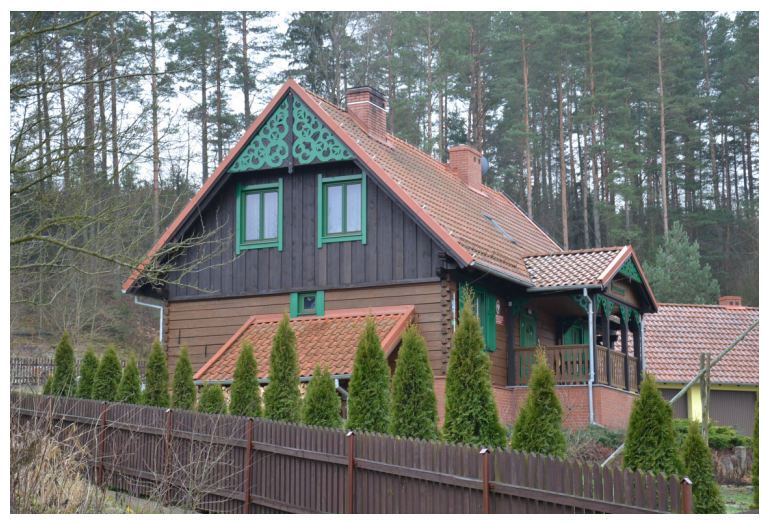

Fig. 2. Brąswałd - traditional countryside architecture

\section{Suburbanisation that is the urban sprawl}

Suburbanisation is a process connected with the development of settlement networks in suburban areas of towns. It often occurs on the land, which is outside the administrative limits of cities, and may spread over the villages, which are then urbanised and mostly contain residential houses. For most residents of such villages, daily commute to town is not a serious problem. The above social and lifestyle changes introduce a new quality in the rural space. New village residents typically live in single-family houses, which often look like prestigious residences. The quality and standard of interior design are different from those in traditional country cottages. The new houses are often built in compact developments and without any farm buildings, which are so characteristic for the rural landscape.

Suburbanisation has many underlying causes. One is the wish to live in one's own house, far from the town's hassle and bustle. This is what drives urban residents to nearby villages. Migration from towns to villages leads to certain transformations of the space, and the style and form of architecture chosen by urban migrants deviate from the local building tradition. The spatial layout of a whole village is also transformed, because new houses are raised in close proximity to one another, in which they resemble suburban housing estates with detached houses. Consequently, regional differences between rural areas disappear [2]. A possible reason could be the low level of social awareness. What 
we observe here, is the illustration of A. Maslow's hierarchy of needs, which identifies dependences between hierarchical levels of human needs and the spatial order management (Fig. 3) [3].

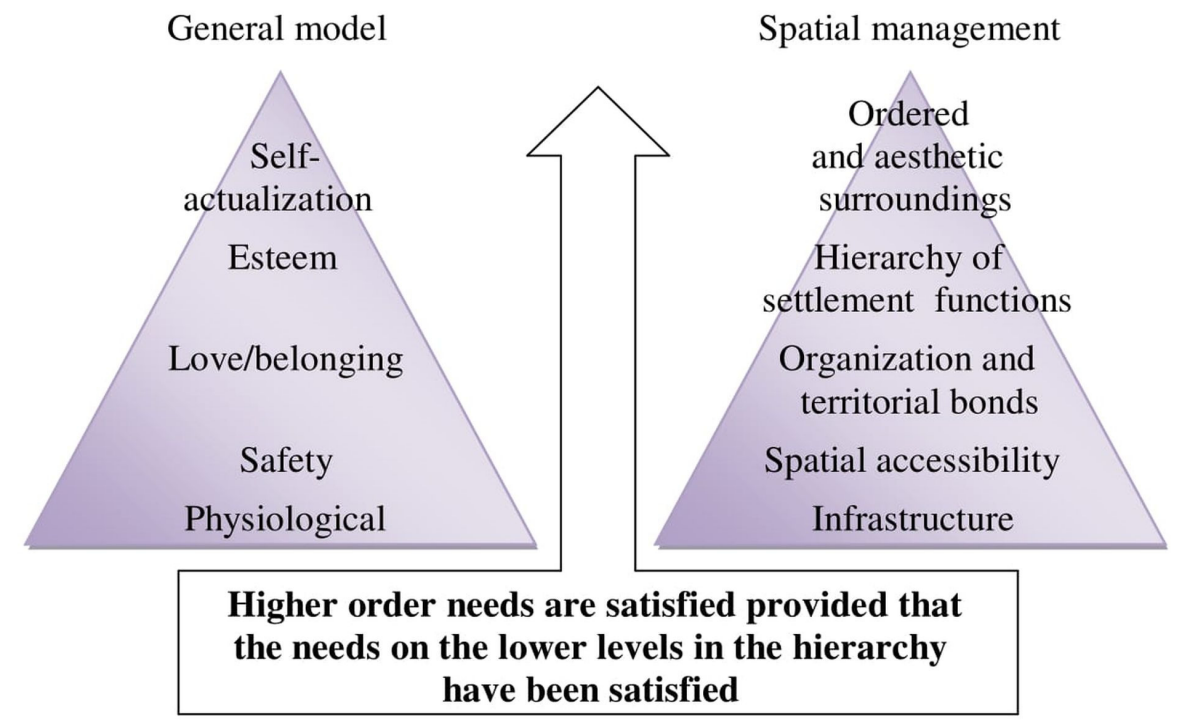

Fig. 3. Connection between A. Maslow's theory of the hierarchy of needs and spatial management

According to the above concept, everyone may have a different attitude to spatial management issues. The need to create order in urbanistic layouts and architecture is located at the top of Maslow's pyramid, and therefore the needs positioned on the lower levels must be satisfied first, before we can enjoy a proper aesthetic order in our ambience. In conclusion, a society on a lower level of development, unfortunately, does not attach much attention to aesthetic values of the environment in which it lives. This relation is rightly worded by P. Śleszyński, who claims that spatial order is a specific emanation of social order [4]. Positive and negative examples can be found in the buildings and their complexes in the rural commune of Dywity (Fig. 4; 5).

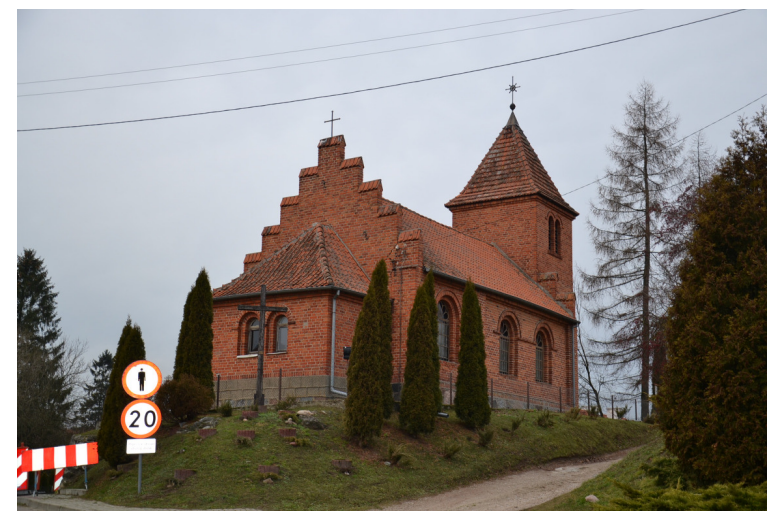

Fig. 4. Church in Bukwałd - a positive example of the region's countryside architecture

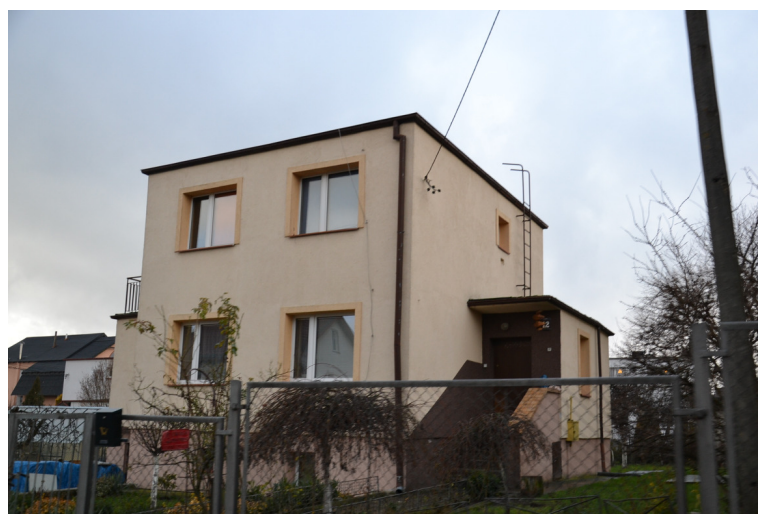

Fig. 5. Kieźliny - a negative example of developing a village

\section{Spatial policy instruments}

The concept of "order" can be viewed from different angles. It can be referred to the surroundings, to the environment and to the space in which we live. "Spatial order" means the order and harmony between various components of the space and functions of the spatial structure. Order in our living space is an expression of the order and harmony of the environment around us. Nowadays, we are often confronted with an inadequately shaped space, which is manifested by the lack of harmony and disagreement with nature. Examples can be found in housing estates in towns, suburban 
districts and in rural areas. With respect to the latter, if they lie in the proximity of a large town, like the commune Dywity, the town per se can be a threatening factor.

Two subsystems are distinguished in the spatial management system. These are: the management and the management principles. The management consists of local authorities, that is the commune's local government, which is responsible for the performance of spatial management tasks in their commune, so as to improve the standard of living for the commune's residents and to ensure spatial order. To this end, the local government uses spatial order instruments, such as the development and implementation of two fundamental documents. They include:

- a study of conditions and directions of spatial management in the commune - the main goal of which is to create order in the spatial management on the local level. The study identifies the current state of management in the commune's territory and defines comprehensive directions in the development of spatial management. This explains why this document must be submitted to the process of obtaining many opinions and reaching numerous agreements before it is passed as a law. Unfortunately, land management in many Polish communes looks very bad - the said studies cover just about $13 \%$ of the area of lands which are suitable for development (Fig. 6);

- a local spatial management plan - a document connected with the aforementioned study, but showing in greater detail the management in specific parcels of land, including parameters and indicators that govern the local building development [5].

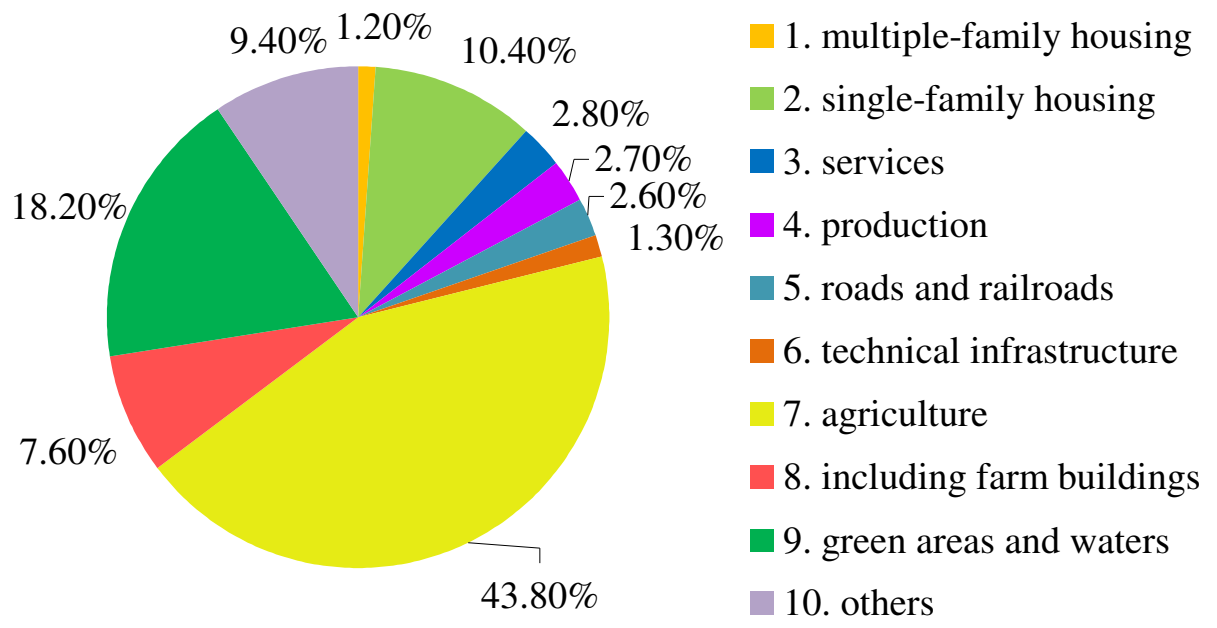

Fig. 6. Structure of purposes for land parcels covered by the commune's studies in 2013

The above local laws are mutually interrelated. The study directs the plan towards further actions to manage the space and organize investment processes, but also to preserve areas of high natural or cultural quality. Then, the plan determines whether a given development project can or cannot be carried out in a specific place. Because we are faced here with a multi-faceted type of action, the plan must perform various functions, such as to regulate protection measures, to provide information, to coordinate activities and to inspire local population [6].

\section{Principles of shaping building developments in rural areas}

In some rural areas of the commune Dywity, due to the vicinity of the town Olsztyn, it is possible to see a mix of urban and rural lifestyle. There are also cases of destruction of the space caused by the previous operation and subsequent liquidation of state-owned farms. As a result, the image of the traditional countryside architecture and layout of villages in Warmia is becoming blurry. This problem is of great concern in other European countries, such as in Germany, Austria or Switzerland. In Switzerland were even special patterns of local architecture used [7]. This destruction threatens the historical solutions, which involved a uniform scale of buildings, similar architectural forms and materials as well as the positioning of houses with their roof ridges either parallel or perpendicular to a road (Fig. 7). 

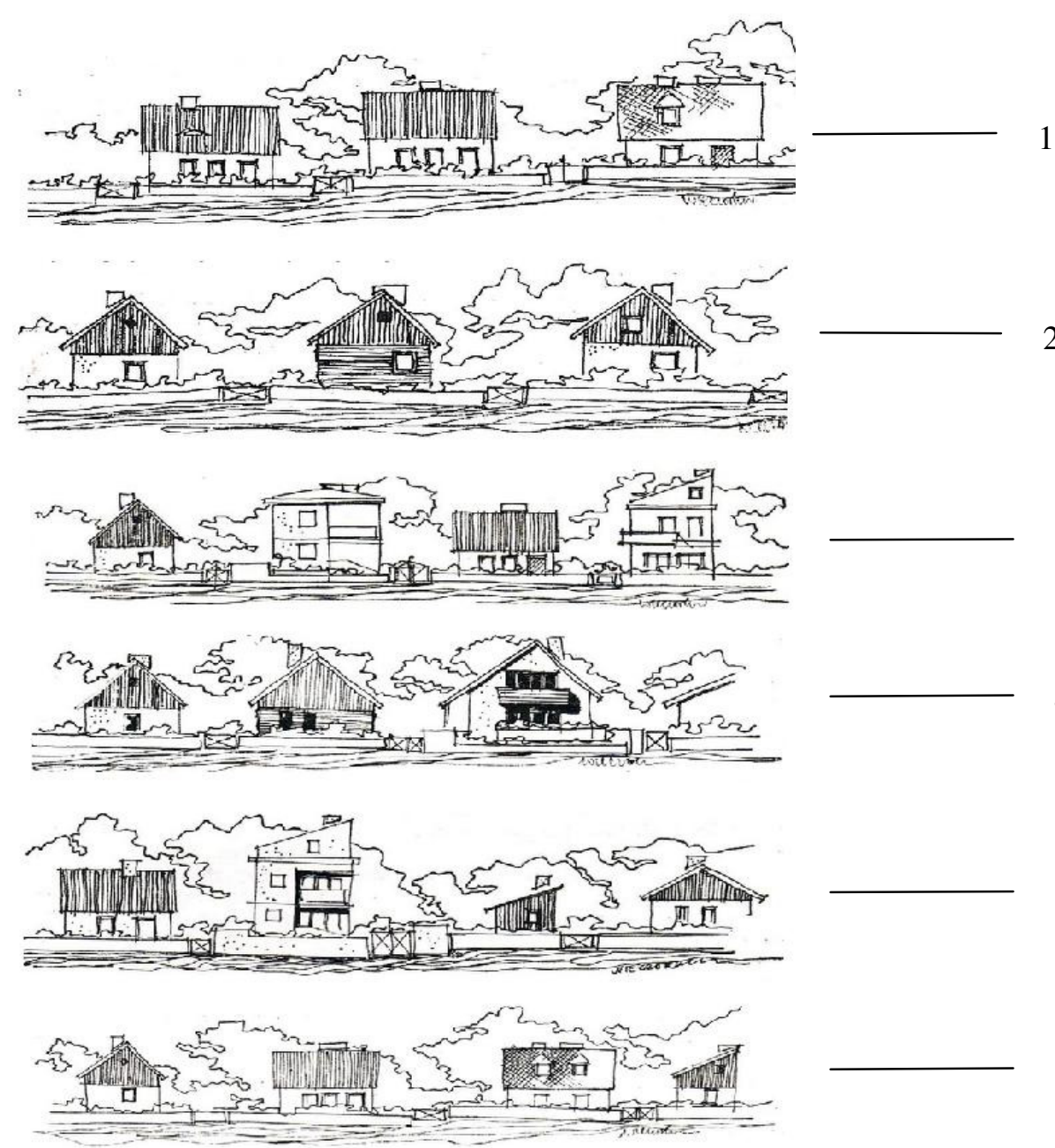

Fig. 7. Spatial and urbanistic layout of ribbon building developments in the countryside:

1 - roof ridges parallel to the road; 2 - roof ridges perpendicular to the road; 3 - diversity of forms brings havoc to the space; 4 - a new building matches the surroundings; 5 - a new building interferes

with the surroundings; 6 - different forms of buildings maintained in the same scale create a harmonious development [8]

Historically, each Polish region had its own, characteristic rural architecture, distinguished by individual features. These distinguishing qualities had stemmed from locally developed ideas of how to plan and construct buildings, how to roof them and what building materials to use. They also incorporated local folk traditions. The above characteristics had been formed under the influences of natural conditions and in response to human settlement, economic and social activities [9]. These values deserve to be preserved, despite different conditions prevalent in the contemporary world.

When shaping the rural space, an effort should be taken to preserve the spatial order and harmony within both a land parcel to be developed and its surroundings. This means that new buildings ought to be positioned according to the traditional housing development, and that the scale, shape, materials, colours and details of planned houses should match the existing buildings. New architecture should be innovative, but its expression needs to inscribe itself into the spatial order on a given complex of buildings. Such efforts help maintain order and harmony in the region's cultural landscape.

\section{Results and discussion}

Increasingly often, the historically developed character of buildings in rural Warmia and Mazury is vanishing before our eyes, and with it the local regionalism is waning. Economic and social transformations have led to a situation where the countryside begins to be dominated by urban type of houses or by innovative rural buildings, which do not have any connection with tradition and do not 
create harmonious links with the landscape. New buildings are often constructed among or in place of old houses, which causes transformation of the character and visual appearance of villages. Today, new urban housing estates, often random in form and shape, are being developed in rural areas. Unfortunately, this trend is irreversible, so we need to be ready to handle its consequences. Housing estates continue to grow and towns "engulf" nearby villages.

\section{Conclusions}

The above observations justify the following conclusions, the aim of which is to prevent the progressing spatial chaos in rural building developments. The measures should focus on the following.

1. A more active spatial policy conducted by rural communes.

2. Development of a larger number of local plans and more stringent regulations regarding new building developments so as to ensure respect of the spatial order.

3. Stricter controls over the issuing building permits and the performance of construction works in compliance with the submitted technical documentation.

4. Gradual elimination, for example through restoration and refurbishment, of buildings, which are disharmonious with the traditional rural landscape.

5. Search for solutions in the proper shaping of contemporary architecture in villages, e.g., developing catalogues of plans of detached houses designed in a style, which is congruent with the regional tradition. Such solutions could inspire architects and investors.

\section{References}

1. Pallasmaa J. Tradition and Modernity: The regional Architecture in Postmodern Society (in:) "Architectural Regionalism. Collected Writings on Place, Identity, Modernity, and Tradition". New York, 2007, p. 133.

2. Burckhardt L. Ästhetik der Landschaft (Aesthetics of the landscape) (in:) "Die Eroberung der Landschaft" (The conquest of the landscape) A a. O., S., p. 67. (In German).

3. Maslow A.H. Motivation and Personality. New York, Harper, 1954.

4. Śleszyński P. Błędy polskiej polityki przestrzennej i krajobrazowej oraz propozycje ich naprawy (Errors in the Polish spatial and landscape policy, and proposed corrective measures). Problemy Ekologii Krajobrazu, 2015, Tom XL, pp. 27-44. (In Polish).

5. Nowak M.J., Mickiewicz P. Plan zagospodarowania przestrzennego województwa - jako instrument zarządzania rozwojem regionalnym (The plan of spatial management for provinces as an instrument of regional development), CeDeWu.pl Wydawnictwo Fachowe, Warszawa, 2012, p. 62. (In Polish).

6. Cymerman R. Podstawy planowania przestrzennego i projektowania urbanistycznego (Foundations of spatial planning and urbanistic design), Wydawnictwo UWM, Olsztyn, 2011, pp. 174-175. (In Polish).

7. Schneider O. Städtebauforderung 1980-1990, 6 Milliarden DM für die Stadt - und Dorferneuerung (Urban development subsidies 1980-1990, 6 billion DM for the city and village renewal), Bonn-Bad-Godesberg, 1988, p. 40. (In German).

8. Radziszewski E. Planowanie przestrzenne i zabudowa wsi (Spatial planning and housing development in the countryside), Arkady, Warszawa, 1983, pp. 129-132. (In Polish).

9. Rieder. P. Economics and Architecture: A Joint Venture (in:) "Cul zuffel e l'aura dado", Quart Verlag, Luzerna, 2004, p. 101. 